\title{
ARTICLES
}

\section{'Human Dignity' as an Indispensable Requirement for Sustainable Regional Economic Integration}

Seung Hwan Choi*

This article proposes the principle of human dignity as an indispensable requirement for sustainable regional economic integration, especially in East Asia. The contribution of free trade to economic growth and development is widely acknowledged. The economic survival of workers and farmers lacking international competitiveness has been, however, endangered, because of the expansion of trade liberalization and investment based on economic integration. Economic integration that ensures human dignity will promote successful and sustainable regional economic integration, by balancing economic prosperity and social integration. In this context, this article reviews the value and concept of human dignity as a goal and principle for regional economic integration. The author contends that neither sustainable prosperity nor a high level of economic development is itself a goal of economic integration, but merely a means by which to improve human dignity. Economic integration should, therefore, serve not only to maintain sustainable prosperity, but also to maximize human dignity.

\section{Keywords}

Human Dignity, Sustainable Economic Integration, Free Trade Agreement, Human Rights Approach, Precautionary Principle

* Professor of International Law at Kyunghee University School of Law, Seoul, Korea. B.A./Ph.D.(SNU), LL.M. (SNU/NYU). This work was supported by the National Research Foundation of Korea Grant funded by the Korean Government MEST, Basic Research Promotion Fund (NRF-2011-013-B00090). The author may be contacted at: tomichoi@khu.ac.kr / Address: 26 Kyunghee-daero, Dongdaemun-gu, Seoul 130-701 Korea. 


\section{Introduction}

Regional trade agreements ("RTAs") have become increasingly prevalent since the early 1990s. As of January 10, 2013, approximately 546 notifications of RTAs (counting goods and services separately) had been received by the General Agreement on Tariffs and Trade ("GATT") ${ }^{1}$ and the World Trade Organization ("WTO"). Of these, 354 were in force. ${ }^{2}$ All RTAs under GATT and WTO systems have in common the status of being reciprocal free trade agreements between two or more member States.

Asian countries are getting more enthusiastic about RTAs. For example, South Korea, despite being a later-comer than the United States ("US") and the European Union ("EU") to the Free Trade Agreement ("FTA"), has actively concluded multiple FTAs since its first FTA with Chile in February 2003. Over the past decade, South Korea has signed 10 FTAs with Chile, Singapore, the European Free Trade Association ("EFTA"), the Association of Southeast Asian Nations ("ASEAN"), India, EU, Peru, US, Turkey and Columbia; it is currently negotiating five more FTAs with Canada, Indonesia, China, Japan-China, and Vietnam. ${ }^{3}$ In addition, negotiations to conclude the Regional Comprehensive Economic Partnership ("RCEP”) are ongoing between ASEAN, South Korea, China, Japan, India, Australia and New Zealand. The ten member States of ASEAN have set a goal of establishing the ASEAN Economic Community by 2015, which may contribute to the creation of an EastAsian Economic Community. ${ }^{4}$

In 2012, meanwhile, negotiations for the Trans-Pacific Partnership Agreement ("TPP”) continued between the following countries: Australia, Brunei Darussalam, Chile, Malaysia, New Zealand, Peru, Singapore, Vietnam, and the US. The 16th round of the TPP negotiations was held from March 4 through 13, 2013, in Singapore. Through the TPP, the US seeks to expand trade and investment in the dynamic AsiaPacific region. ${ }^{5}$ Once concluded, the TPP will become the most important RTA in the

1 General Agreement on Tariffs and Trade, Oct. 30, 1947, 61 Stat. A3, T.I.A.S. 1700, 55 U.N.T.S. 187. The GATT was modified and superseded in part by the GATT 1994, one of the WTO Agreements. The original GATT is now known as the GATT 1947.

2 For details on the RTAs notified to the WTO, see the RTA Database, available at http://rtais.wto.org/UI/ PublicMaintainRTAHome.aspx (last visited on Mar. 18, 2013).

3 For details on the current status of and textbooks about the FTAs of Korea, see FTA Status of ROK, available at $\mathrm{http}$ :/www.mofat.go.kr/ENG/policy/fta/status/overview/index.jsp?menu=m_20_80_10 (last visited on Apr. 8, 2013).

4 See ASEAN Economic Community, available at http://www.asean.org/communities/asean-economic-community (last visited on Apr. 8, 2013). For details on the East Asian Community, see Y. Sato Immigration Law and Policy of Japan in the Age of East Asian Community Building, 3 J. EAST AsIA \& INT'L L. 296-299 (2010).

5 The 11 countries (Australia, Brunei Darussalam, Canada, Chile, Malaysia, Mexico, New Zealand, Peru, the United 
world, as it will include some of the biggest players such as the US, Australia, South Korea, Japan and possibly even China.

With the expansion of regional economic integration in pursuit of economic development and prosperity between the WTO Members, the voices of many nongovernmental organizations ("NGOs") and interest groups opposing regional economic integration are also becoming louder. The Doha Development Agenda ("DDA") negotiations, officially launched at the WTO's Fourth Ministerial Conference in Doha, Qatar, in November 2001, have been deadlocked since 2002, because of conflicting interests between developed and developing countries, and systematic movement by some interested groups against the liberalization of trade and globalization. ${ }^{6}$ In spite of differing opinions on the effect of globalization on national legal systems, trade liberalization has significantly influenced, directly and indirectly, the daily life of individuals. ${ }^{7}$ Trade competition has resulted in maximizing profit at the expense of workers and the environment. It is thus fair to say that: "Trade interests dominated the political systems of many States, causing the economically weaker majorities to sacrifice their interests for the interests of the economically strong."

The contribution of free trade to economic growth and development is widely acknowledged. ${ }^{9}$ Lacking international competitiveness, however, traditional workers and farmers have been threatened by opening markets and economic integration. They complain that trade liberalization will widen the gap between the strong and the weak, the rich and the poor. ${ }^{10}$ Violations of basic labor rights and discriminatory treatment against irregular workers have undermined the social integration that is

States, Singapore and Vietnam) made progress during this round by continuing to develop comprehensive packages that will provide market access for goods, services and investment, and government procurement. See MTI Press Release - End of TPP Round 16 in Singapore, available at http://www.fta.gov.sg/press_home_detail.asp?id=223\&txt_ rdate $=2013 \&$ txt_ftalist $=0$ (last visited on Mar. 18, 2013).

6 For example, world-wide NGOs such as the Global Policy Forum, the World Wide Fund for Nature ("WWF"), and the Third World Network ("TWN") have strongly opposed globalization in its current form, a system in which powerful corporations make the rules for their own benefit. Korean and Japanese farmers continued to join other NGO groups from Asian countries in anti-globalization protests at the WTO Ministerial Conference in Seattle and those following it. Regarding the anti-globalization protests and global justice movements against trade liberalization, see A. Lang, World Trade Law after Neoliberalism: Re-imagining the Global Economic Order 61-81 (2011).

7 For details on the impacts of WTO law on national States' legal system, see Guiguo Wang, Radiating ImPact OF WTO on Its Members' Legal System: The Chinese Perspective (2011).

8 K. Schefer, Social Regulations in the WTO: Trade Policy and International Legal Development 8 (2010).

9 J. Jackson et al., Legal Problems of International Economic Relations: Cases, Materials and Text 4-18 (4th ed. 2002). The process of globalization and economic integration has helped many countries to benefit from high rates of economic growth and employment creation, to absorb many of the rural poor into the modern urban economy, to advance their developmental goals, and to foster innovation in product development.

10 For details on the arguments against free trade made by workers and farmers, see supra note 6, at 61-76. 
indispensable for sustainable economic development and prosperity. ${ }^{11}$

In this context, this research will suggest the principle of 'human dignity' as an indispensable requirement for sustainable regional economic integration. The main purpose of human dignity is to minimize the negative impacts of globalization on the everyday life of individuals. Arguably, economic integration that ignores human dignity cannot ensure sustainable regional economic development. Human dignity will promote successful and sustainable regional economic integration by balancing economic expansion and social justice. It should not be sacrificed for the sake of economic benefits.

This paper is divided into five parts, including Introduction and Conclusion. Part two will examine the value and concept of human dignity as fundamental to sustainable regional economic integration. Here, sustainable economic integration will be reviewed in terms of protection of human dignity and rights. Part three will examine some substantive rules for sustainable economic integration to ensure human dignity. Part four will propose some procedural rules for sustainable economic integration to ensure human dignity.

\section{Human Dignity as a Fundamental Value of Sustainable Regional Economic Integration}

\section{A. Human Dignity as a Goal}

In general, maximizing benefits through expansion of free trade and investment is the express goal of regional economic integration. ${ }^{12}$ For example, the objectives of the Korea-EU FTA are to liberalize and facilitate trade in goods, to liberalize trade in services and investment, and to promote foreign direct investment between

11 See ILO Declaration on Social Justice for a Fair Globalization, Jun. 10, 2008, pmbl., available at http://www.ilo.org/ wcmsp5/groups/public/---dgreports/---cabinet/documents/genericdocument/wcms_099766.pdf (last visited on Apr. 9, 2013). It provides: "Global economic integration has caused many countries and sectors to face major challenges of income inequality, continuing high levels of unemployment and poverty, vulnerability of economies to external shocks, and the growth of both unprotected work and the informal economy, which impact on the employment relationship and the protections it can offer."

12 The importance of free trade for economic growth and development is based on the theory of comparative advantage. Neoliberal thinking about international trade also emphasizes the role of free trade and economic globalization in economic growth and development. See supra note 9, at 7-8, 450; M. Trebilcock \& R. Howse, The Regulation of InTERNATIONAL TRADE 3-4 (1998); supra note 6, at, 54. 
the Parties. ${ }^{13}$ In addition, the Korea-EU FTA sets up policy objectives "to raise living standards, promote economic growth and stability, create new employment opportunities, and improve the general welfare in their territories by liberalizing and expanding trade and investment between their territories." ${ }^{14}$ In the Framework Agreement on Comprehensive Economic Cooperation between the Governments of the member countries of ASEAN and South Korea, both parties set up the objectives of regional economic integration "as to strengthen and enhance economic, trade and investment cooperation, to progressively liberalize and promote trade in goods and services, and to explore new areas and develop appropriate measures for closer economic cooperation and integration." ${ }^{15}$

However, maximizing trade benefits through regional economic integration should not be considered the final goal of regional economic integration. Economic development or a high standard of living brought about by trade and investment liberalization is merely a means of promoting human dignity. Neither economic interest nor trade benefits can impair human dignity; trade benefits are useful so long as they contribute to human dignity. The goal of regional economic integration is to realize harmonization of economic development with human dignity. ${ }^{16}$

\section{B. Human Dignity as a Basic Legal Principle}

Human dignity is a basic legal principle of sustainable regional economic integration. As human dignity cannot be given up for the sake of economic benefit, it must be a guiding legal principle of regional economic integration agreements. According to the 2004 EU Constitution, the EU is explicitly "founded on the values of respect for human dignity, freedom, democracy, equality, the rule of law, and respect for human rights, including the rights of persons belonging to minorities. ${ }^{17}$ In the 29/69 Stauder

13 Free Trade Agreement between the Republic of Korea, of the One Part, and the European Union and Its Member States, of the Other Part, art. 1.1 [hereinafter Korea-EU FTA], available at http://www.fta.go.kr/new/pds/fta_korea/ eu/kor_eu_list2.html (last visited on Jan. 25, 2013).

14 Free Trade Agreement between the Republic of Korea and the United States of America, pmbl. [hereinafter KOR-US FTA], available at http://www.fta.go.kr/korus/pds/kor_us_list_en.html (last visited on Jan. 25, 2013).

15 Framework Agreement on Comprehensive Economic Cooperation among the Governments of the Member Countries of the Association of Southeast Asian Nations and the Republic of Korea, Dec. 13, 2005, art. 1.1, available at http:// www.asean.org/news/item/asean-republic-of-korea-free-trade-area-2 (last visited on Mar. 15, 2013).

16 According to the Kantian postulate, no man has the right to use another person merely as a means to attain his own subjective purposes, but human beings should be always treated as ends in themselves. See E. BodENHEIMER, Jurisprudence: The Philosophy and Method of the Law 62 (1981).

17 See Treaty Establishing a Constitution for Europe art. I-2, 2004/C 310/01, available at http://eur-lex.europa.eu/JOHtml. do?uri=OJ:C:2004:310:SOM:EN:HTML; Consolidated version of the Treaty on European Union art. 2, 2010/C 83/01, available at http://eur-lex.europa.eu/JOHtml.do?uri=OJ:C:2010:083:SOM:EN:HTML (all last visited on Mar. 
case, the European Court of Justice ("ECJ") confirmed for the first time that protection of human rights is part of the general principles of the European Communities ("EC") law. ${ }^{18}$

The ultimate goal of legal control as conceived by Lasswell and McDougal is "a world community in which ... the protection of human dignity is regarded as a paramount objective of social policy." ${ }^{19}$ Without basic human rights, people cannot adequately enjoy human dignity and the eight values of power, wealth, enlightenment, skill, well-being, affection, respect, and rectitude. ${ }^{20}$ John Shijian Mo also contended that: "Human dignity and the eight values endorsing it must be the basic values for assessing and guiding the negotiation and operation of China's FTAs" under the "human dignity compliance principle." ${ }^{21}$

All States have a legal obligation under the Charter of the United Nations to promote universal respect for and observance of human rights and freedoms. ${ }^{22}$ All UN human rights conventions, including the Covenant on Civil and Political Rights ("ICCPR") and the Covenant on Economic, Social, and Cultural Rights ("ICESCR") recognize in their Preambles that human rights are "derive[d] from the inherent dignity of the human person." ${ }^{23}$ Since the economic, social, and cultural rights incorporated in ICESCR are "to a large extent those rights which are most directly threatened by a free trade system," 24 the protection of human rights through the principle of human dignity should function as a legal basis not only for implementing trade restrictions, but also for limiting trade restrictions. ${ }^{25}$ Although national and

15, 2013).

18 Erich Stauder argued that an EC requirement conditioning the distribution of subsidized butter to the poor on disclosure of the name of beneficiaries violated his constitutional right to respect for dignity protected by the German Basic Law. The ECJ interpreted the EC rule in conformity with human rights as not requiring identification of beneficiaries by name. See Judgment of the Court of 12 November 1969, Erich Stauder v. City of Ulm - Sozialamt (Reference for a preliminary ruling by the Verwaltungsgericht Stuttgart), Case 29-69 [1969] ECR 419, at 425, available at http:// curia.europa.eu/juris/liste.jsf?language=en\&td=ALL\&jur=C,T,F\&num=29/69 (last visited on Mar. 15, 2013).

19 Supra note 16, at 150.

20 For details on these eight values, see H. Lasswell \& M. Mcdougal, Jurisprudence for a Free Society, vol. I, 399590 (1992).

21 John Shijian Mo argues that: "Under this principle, the government should stipulate the private rights in as detailed a manner as possible to ensure the realization of these values." See J. Shijian Mo, A 'New Haven' Solution to the Protection of Private Rights in China's FTAs, 19 Asia PACIFIC L. Rev. 151 (2011).

22 U.N. Charter arts. 55 \& 56.

23 Id. pmbl.

24 Supra note 8, at 57.

25 Id. It reads: "The human rights dimension to the question of trade regulations' legitimacy in international law has two main aspects: the protection of human rights as a reason for implementing trade restrictions; and the protection of human rights as a reason for limiting trade restrictions. Easily reconcilable, each of the aspects is noteworthy in assessing the legitimacy of trade restrictions in international law." 
international human rights instruments define human rights in different ways, there is strong evidence for and consensus that the core of human rights such as the rights to life and adequate food, respect for human dignity, freedom from torture and slavery, rights not to be discriminated against and to judicial protection necessary for the enjoyment of other rights, have evolved into "international constitutional law and jus cogens which may neither be suspended nor subordinated to other rights." ${ }^{26}$

Because the principle of human dignity is a basic norm justifying all legal regulations and institutions, it must have priority over trade and investment liberalization, in case of conflicts with other provisions under regional economic integration agreements. It should be noted that in the event of a conflict between the obligations of the Members under the UN Charter and their obligations in accordance with any other international agreement, their obligation under the Charter shall prevail in accordance with Article 103 of the Charter. Thus, "the UN has succeeded in moving from a static concept of human rights ... to a dynamic doctrine which goes so far as to promote conflict and the disruption of the status quo for the sake of introducing social justice and respect for human rights." ${ }^{27}$

\section{Substantive Rules for Sustainable Economic Integration Ensuring Human Dignity}

Substantive rules for sustainable economic integration may be an effective means to ensure human dignity under an economic integration agreement, because they can create the official right to seek legal remedy when fundamental human rights are impaired by the application and implementation of regional economic integration agreement. In this section, substantive rules for sustainable economic integration, not in terms of environmental protection but in terms of human rights, will be proposed.

\section{A. Human Rights Approach to International Trade}

Trade regulations against significant violation of human rights may be used as an effective means to protect human dignity. Basic human rights should be recognized

26 E.-U. Petersmann, International Economic Law in the 21 st Century 356 (2012).

27 A. Cassese, International Law 397 (2005). 
by those regulations, and take precedence over economic considerations. However, existing laws and regulations under WTO and FTAs do not contain any explicit reference to human rights. ${ }^{28}$ The general exception of Article 20(e) of the GATT 1994 is the only provision directly relating to human rights. ${ }^{29}$ It allows members to take trade measures against the products of prison labor, on the condition that "such measures are not applied in a manner which would constitute a means of arbitrary or unjustifiable discrimination between countries where the same conditions prevail, or a disguised restriction on international trade." ${ }^{30}$

Unlike other FTAs, the NAFTA has a separate agreement on labor and environment that may be applied to protect human rights relating to labor and environment. ${ }^{31}$ The Korea-US FTA also has provisions on labor cooperation (Chapter 19) and environmental cooperation (Chapter 20). Under Article 19.2, South Korea and the US must adopt and maintain in their statutes and regulations, and practices thereunder, the following rights, as stated in the ILO Declaration on Fundamental Principles and Rights at Work and its Follow-Up ${ }^{32}$ (hereinafter ILO Declaration): (a) freedom of association; (b) the effective recognition of the right to collective bargaining; (c) the elimination of all forms of compulsory or forced labor; (d) the effective abolition of child labor and, for purposes of this Agreement, a prohibition on the worst forms of child labor; and (e) the elimination of discrimination in respect of employment and occupation." 33

The UN High Commissioner for Human Rights (“UNHCHR”) published reports reviewing the human rights dimensions of the WTO Agreements on TRIPs, ${ }^{34}$ the

28 "To the extent that the principle of non-discrimination (MFN and National Treatment) also protects people as service providers under GATS or holders of intellectual property rights," they may be interpreted or applied in terms of human rights of non-discrimination and equality. See T. Cottier, Genetic Engineering, Trade and Human Rights, in Biotechnologies and International Human Rights 284 (F. Francioni ed., 2007).

29 The GATT/WTO 'general exceptions' to protect human rights may include, e.g., protection of 'public morals,' "human, animal, or plant life or health," "essential security interests," and 'public order.'

30 GATT 1994 art. 20(e) \& chapeau.

31 North American Agreement on Labor Cooperation ("NAALC"); North American Agreement on Environmental Cooperation ("NAAEC").

32 See the full text of ILO Declaration on Fundamental Principles and Rights at Work and its Follow-up, Annex (adopted on Jun. 18, 1998; revised on Jun. 15, 2010), available at http://www.ilo.org/declaration/thedeclaration/ textdeclaration/lang--en/index.htm (last visited Apr. 9, 2013).

33 Korea-US FTA art 19.2 (n. 2). It reads: "To establish a violation of an obligation under Article 19.2.1 a Party must demonstrate that the other Party has failed to adopt or maintain a statute, regulation, or practice in a manner affecting trade or investment between the Parties."

34 See The Impact of the Agreement on Trade-Related Aspects of Intellectual Property Rights on Human Rights, U.N. Doc. E/CN.4/Sub.2/2001/13 (Jun. 27, 2001), available at http://documents-dds-ny.un.org/doc/UNDOC/GEN/ G01/143/45/pdf/G0114345.pdf?OpenElement (last visited on Apr. 8, 2013). 
Agreement on Agriculture, ${ }^{35}$ the General Agreement on Trade in Services ("GATS"), international investment agreements, ${ }^{37}$ non-discrimination, ${ }^{38}$ and the highest standard of health. ${ }^{39}$ The reports called for a human rights approach to trade which:

(a) sets the promotion and protection of human rights among the objectives of trade liberalization;

(b) examines the effects of trade liberalization on individuals and seeks trade law and policy that take into account the rights of all individuals, in particular vulnerable individuals and groups;

(c) emphasizes the role of the State in the process of liberalization - not only as negotiators of trade law and setters of trade policy, but also as the primary duty bearer for the implementation of human rights;

(d) seeks consistency between the progressive liberalization of trade and the progressive realization of human rights;

(e) requires a constant examination of the impact of trade liberalization on the enjoyment of human rights; and

(f) promotes international cooperation for the realization of human rights and freedoms in the context of trade liberalization. ${ }^{40}$

As pointed out by the UNHCHR, most of the WTO members ratified one or more UN human rights conventions; fundamental human rights would be regarded as universal norms under general international law, considering that 112 members of the WTO have ratified the International Covenant on Economic, Social and Cultural Rights (“ICESCR”). Since fundamental human rights are established as customary international law, "trade rules should be interpreted as consistent with those norms

35 See Globalization and its Impact on the Full Enjoyment of Human Rights, U.N. Doc. E/CN.4/2002/54 (Jan. 15, 2002), available at http://documents-dds-ny.un.org/doc/UNDOC/GEN/G02/101/08/pdf/G0210108.pdf?OpenElement (last visited on Apr. 8, 2013).

36 See Liberalization of Trade in Services and Human Rights, U.N. Doc. E/CN.4/Sub.2/2002/9 (Jun. 25, 2002), available at http://documents-dds-ny.un.org/doc/UNDOC/GEN/G02/141/14/pdf/G0214114.pdf?OpenElement (last visited on Apr. 8, 2013).

37 See Human Rights, Trade and Investment, U.N. Doc. E/CN.4/Sub.2/2003/9 (Jul. 2, 2003), available at http:// documents-dds-ny.un.org/doc/UNDOC/GEN/G03/148/47/pdf/G0314847.pdf?OpenElement (last visited on Apr. 8, 2013).

38 See Analytical Study of the High Commissioner for Human Rights on the Fundamental Principle of Non-Discrimination in the Context of Globalization, U.N. Doc. E/CN.4/2004/40 (Jan.15, 2004), available at http://documents-dds-ny. un.org/doc/UNDOC/GEN/G04/103/57/pdf/G0410357.pdf?OpenElement (last visited on Apr. 8, 2013).

39 See The Right of Everyone to the Enjoyment of the Highest Attainable Standard of Physical and Mental Health, U.N. Doc. E/CN.4/2004/49 (Mar. 1, 2004), available at http://documents-dds-ny.un.org/doc/UNDOC/GEN/G04/109/33/ pdf/G0410933.pdf?OpenElement (last visited on Apr. 8, 2013).

40 Supra note 36, at 2. 
and standards whatever the treaty commitments of States in trade matters." ${ }^{41}$ In other words, Members of WTO and Parties to FTAs should protect human rights in the course of applying and implementing rules on trade liberalization. Therefore, the human rights approach to international trade rules "sets as entitlements the basic needs necessary to lead a life in dignity and ensures their protection in the processes of economic liberalization." 42 Thus, States are responsible for ensuring that these entitlements cannot be "left subject to the whim of markets." ${ }^{43}$ Such a fundamental nature of human rights requires the promotion and protection of human rights as primary objectives of trade liberalization, not as exceptions. ${ }^{44}$

The objective of the WTO dispute settlement system is to clarify the existing provisions of those agreements "in accordance with customary rules of interpretation of public international law." ${ }^{\prime 4}$ In this context, the human rights approach to international trade must be recognized as a guiding principle at the negotiation and implementation of regional economic integration agreement. The UN Charter notes that: "In the event of a conflict between the obligations of the Members of the United Nations under the present Charter and their obligations under any other international agreement, their obligations under the present Charter shall prevail." ${ }^{46}$

The Vienna Covenant on the Law of Treaties ("VCLT") also affirms that: "Disputes concerning, like other international disputes, ... should be settled in conformity with the principle of justice and international law," including "universal respect for, and observance of, human rights and fundamental freedoms for all." ${ }^{\text {" }}$ At the 73rd Conference of the International Law Association ("ILA"), held in August, 2008, members of the Committee of International Trade Law agreed that States have human rights obligations, according to the UN Charter and human rights conventions as well as under customary international law and general principles of international law. They declared that: "WTO members and bodies are legally required to interpret and apply WTO rules in conformity with the human rights

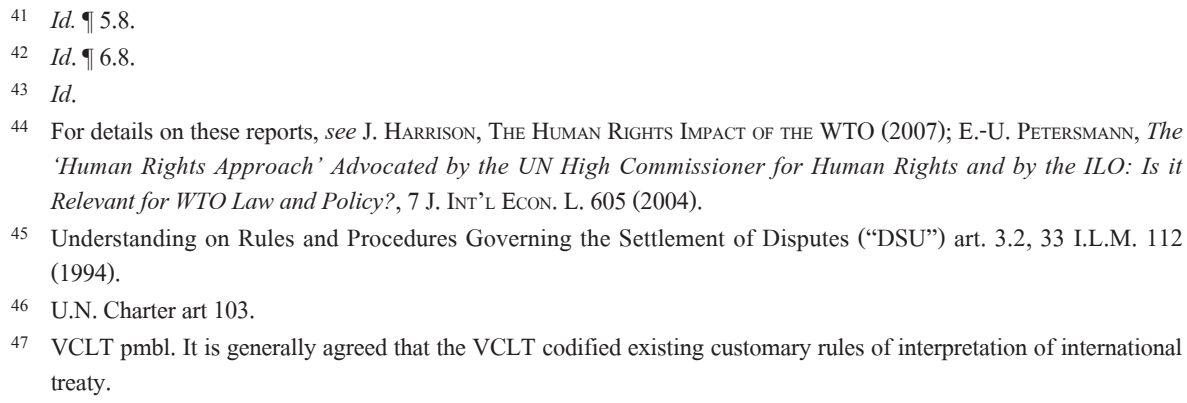

45 Understanding on Rules and Procedures Governing the Settlement of Disputes ("DSU") art. 3.2, 33 I.L.M. 112 (1994).

46 U.N. Charter art 103.

47 VCLT pmbl. It is generally agreed that the VCLT codified existing customary rules of interpretation of international treaty. 
obligations of WTO members under international law." ${ }^{48}$

According to the basic rules and consensus of the international community, eventually the protection of basic human rights in trade regulations must be recognized as core concepts in, not as exceptions to, regional economic integration agreements. Members should be entitled to take trade measures necessary to protect basic human rights when other Members or foreign companies abuse basic human rights.

\section{B. Measures to Improve Food Security}

"Access to adequate food" is recognized as a fundamental human right. It is widely agreed that "under international law there is currently found, to a minimal extent, a treaty right conjoined with a customary right to be free from hunger." ${ }^{49}$ This view has been supported by the Universal Declaration of Human Rights ("UDHR") ${ }^{50}$ and ICESCR. ${ }^{51}$ In the Rome Declaration on World Food Security, government delegates reaffirmed "the right of everyone to have access to safe and nutritious food, consistent with the right to adequate food and the fundamental right of everyone to be free from hunger..." 52 Therefore, measures to improve food security may be used as an effective means of protecting fundamental human rights.

\section{Tariff Reductions and Special Safeguard Measures}

A special consideration should be given to key staple crops or basic food security crops in tariff reduction commitments. This may include exemption from the reduction commitment. Developing countries should have the flexibility to apply lower rates of reduction and implement the reduction commitments over a longer period. Tariff rate quotas ("TRQs") were introduced in the Uruguay Round to ensure that existing access conditions were not undermined and as a means to create new market access opportunities. Since TRQs have greatly contributed to increasing market access and the food security of net-food importing countries, current tariff volume and in-quota tariff rates should be maintained and much flexibility for the TRQ administration

\footnotetext{
48 Resolution 5/2008, adopted by International Trade Law Committee; the 8th Report of International Trade Law Committee, adopted at the 73rd Conference of the International Law Association, held in Rio de Janeiro, Brazil, August 17-21, 2008, $\mathbf{\uparrow \uparrow ~ 3 8 - 4 2 . ~}$

49 D. Buckingham, A Recipe for Change: Towards an Integrated Approach to Food under International Law, 6 PACE Int'L L. Rev. 290-296 (1994). See also M. Footer, Agricultural Biotechnology, Food Security and Human Rights, in Biotechnology and International Law 261 (F. Francioni \& T. Scovazzi eds., 2006).

50 UDHR art. 25.1.

51 ICESC art. 11.

52 Rome Declaration on World Food Security, Nov. 13, 1996, ๆ 1.
} 
should be given to the basic food security crops of net-food importing countries.

The special safeguard ("SSG") provisions help to address food security by safeguarding vulnerable domestic agricultural production from import surges. The WTO Agreement on Agriculture allows Members to take special emergency action to restrict imports in cases of imports surges (when imports of a product exceed a trigger level) or falling prices (when the price of a product falls below a trigger price equal to the average 1986 to 1988 reference price). ${ }^{53}$ Most of the FTAs that Korea signed with the US, the EU and Chile also have a special emergency clause for agricultural products. ${ }^{54}$ Given the special nature of agricultural products, the SSG system should be continued to minimize serious injuries caused to domestic industry by sudden import surges and price fluctuations in food security crops. Consideration should be also given for local food security crops.

\section{Domestic Support}

Given the uncertainty of food supply in the world food market, there will always remain a threat to food security. Since agricultural production is biological and site-specific, demand and supply in agriculture is very inelastic. Supply is greatly dependent on the weather and very sensitive to climate change. For example, over $90 \%$ of global rice production depends on the same monsoon area. ${ }^{55}$

The importance of domestic production for food security was emphasized by many commentators. ${ }^{56}$ The heavy dependency on imported foods and food aid is too risky, especially to net-food-importing countries, because it can foreclose the potential of domestic production as both an engine of rural development and an effective means to achieve sustainably food security. ${ }^{57}$ The success of agriculture, based on substantial improvement in productivity, is important to the economy as well as to food security, because nearly $80-90 \%$ of developing countries are directly dependent on agriculture for their food and livelihood. ${ }^{58}$ It is quite risky

53 Agreement on Agriculture art. 5.1.

54 KOR-US FTA art. 3.3; Korea-EU FTA art. 3.6; Free Trade Agreement between the Government of the Republic of Korea and the Government of the Republic of Chile art. 3.12 [hereinafter Korea-Chile FTA], available at http:// www.fta.go.kr/pds/fta_korea/chile/eng/Text_of_Agreement.pdf (last visited on Feb.25, 2013).

55 S. Murphy, Structural Distortions in World Agricultural markets: Do WTO Rules Support Sustainable Agriculture?, 27 Colum. J. EnvtL. L. 610 (2002).

56 OeCD, Multifunctionality: Towards an Analytical Framework 48 (2001), available at http://www.peblds.org/ files/Publications/OECD/OECD_Multifunctionality $\% 20$ towards $\% 20 \mathrm{an} \% 20$ analytical $\% 20$ framwork.pdf (last visited on Feb.25, 2013).

57 Seung Hwan Choi, Food Security and the Doha Development Agenda Negotiations on Agriculture: A Korean Perspective, in WTO and East Asia: New Perspectives 187 (M. Matsushita \& Dukgeun Ahn eds., 2004).

58 M. Taylor, The Emerging Merger of Agricultural and Environmental Policy: Building a New Vision for the Future of 
for a country to secure its source of food through foreign trade. A certain degree of stable domestic food production is thus very important for both developed and developing countries, ${ }^{59}$ in terms of "national safety and security. ${ }^{60}$ In this sense, all domestic support to improve domestic production of basic food security crops must be exempted from any form of domestic support reduction commitments.

Reflecting more properly food security concerns, the exemption from reduction commitment should be provided for the following supports: (1) maintaining domestic production capacity crops, based on food security purposes, such as direct payment for farm households and farmland conservation; (2) enhancing flexible income safety net programs responsive to reduced income risks increased by market liberalization, climate change and price fluctuations; (3) continuing existence and productivity enhancement of small-scale family farms; and (4) agricultural and rural development in developing countries. ${ }^{61}$

\section{Export Restrictions}

Export restrictions may be necessary for the food security of food-exporting countries in cases of emergencies like food shortages. Export restrictions may, however, have detrimental effects on the food security of food-importing countries by increasing price variability and uncertainty. ${ }^{62}$ For this reason, the Agreement on Agriculture obligates the member instituting export restrictions to give due consideration to the effects of such restrictions on importing Members' food security. ${ }^{63}$

Rules and disciplines regarding export restrictions should be, therefore, established, and, where existing, strengthened in order to prohibit countries from imposing restrictions arbitrarily for the purpose of curtailing exports. ${ }^{64}$ Members

American Agriculture, 20 VA. ENVTL. L. J. 184 (2001).

59 Supra note 57 , at 186.

60 J. Miller, Globalization and Its Metaphors, 9 Minn. J. Global Trade 597 (2000).

61 Supra note 57, at 193-194.

62 Id. at 196. See Negotiations on WTO Agreement on Agriculture: Proposals by India, G/AG/NG/W/102, Jan. 15, 2001, available at $\mathrm{https} / /$ docs.wto.org/dol2fe/Pages/FE_Search/FE_S_S006.aspx?MetaCollection=WTO\&Symbol List="G/AG/NG/W/102"+OR+"G/AG/NG/W/102/*"\&Serial=\&IssuingDateFrom=\&IssuingDateTo=\&CATTITLE $=\&$ ConcernedCountryList $=\&$ OtherCountryList $=\&$ SubjectList $=\&$ TypeList $=\&$ AutoSummary $=\&$ FullText $=\&$ FullText Form $=\&$ ProductList $=\&$ BodyList $=\&$ OrganizationList $=\&$ ArticleList $=\&$ Contents $=\&$ CollectionList $=\&$ RestrictionType Name $=\&$ PostingDateFrom $=\&$ PostingDate $\mathrm{To}=\&$ DerestrictionDateFrom $=\&$ DerestrictionDateTo $=\&$ ReferenceList $=\&$ Language $=$ ENGLISH\&SearchPage $=$ FE_S_S001\&ActiveTabIndex $=0 \& \&$ languageUIChanged $=$ true $\#$ (last visited on Apr. 9, 2013).

63 Agreement on Agriculture art. 12.1(a).

64 See Proposal for WTO Negotiations on Agriculture, submitted by the Republic of Korea, G/AG/W/98, Jan. 9, 2001, ๆ 25; Negotiating Proposal by Japan on WTO Agricultural Negotiations, G/AG/NG/W/91, Dec. 21, 2000, ๆ 33; WTO Negotiations on Agriculture-Cairns Group Negotiation Proposal, G/AG/NG/W/93, Dec. 21, 2000, available at http:// 
instituting such export restrictions, except developing country Members that are not net exporters of the product concerned, must give notice in writing to the Committee on Agriculture before introducing new export restrictions on foodstuffs, must consult, upon request, with affected Members having a substantial interest as importers with respect to any matter related to the measure in question, and must provide, upon request, any such Member with necessary information. ${ }^{65}$

\section{Food Safety and the Precautionary Principle}

Access to adequate food is necessary for good nutrition. However, it is not in itself sufficient to protect the right to food, because food must be safe enough for people to survive and remain free from disease. As pointed out by Cottier, "[t]he protection of food safety inherently relates to the right to food and serves the protection of the right to health and life." ${ }^{66}$ Food security inevitably includes food safety in terms of the right to food and life. The GATT 1994 and the WTO Agreement of the Application of Sanitary and Phytosanitary Measures (hereinafter SPS Agreement) recognize a Member's right to take measures necessary for the protection of human life and health. ${ }^{67}$ Without the confidence of consumers in food safety, trade liberalization cannot be accomplished successfully.

Precautionary measures for food safety must be, therefore, recognized in due consideration of consumers' concerns about food safety. It is relevant to share here that the gravity of risks to human health from the consumption of genetically modified organisms ("GMOs") is disputed and could be potentially serious in the future. ${ }^{68}$ Many people are concerned about the risk posed by the GMO foods and their short and long-term effects on human health. If genetically modified crops not suitable for human consumption enter the human food chain, they are likely to create potential adverse effects on human health and life. The main concerns about those crops and foods relate to allergens, toxins, antibiotic resistance, and other unexpected adverse effects on human health. ${ }^{69}$

Consequently, the precautionary principle for food safety must be adopted as

www.wto.org/english/tratop_e/agric_e/negs_bkgrnd09_taxes_e.htm (last visited Apr. 9, 2013).

65 Agreement on Agriculture art.12.1(b).

66 T. Cottier, Genetic Engineering, Trade and Human Rights, in BIOTECHNOLOGIES AND InTERNATIONAL Human RIGHTS 294 (F. Francioni ed., 2007).

67 GATT 1994 art. 20(b); SPS Agreement art. 2.

68 According to Article 3 of the Cartagena Protocol on Biosafety, a genetically modified organism or living modified organism ("LMO") means "any organism that possesses a novel combination of genetic material obtained through the use of modern biotechnology."

69 M. Lee, EU Regulation of GMOs 28 (2008). 
a basic legal principle under regional economic integration agreement. ${ }^{70}$ The Rio Declaration on Environment and Development (hereinafter Rio Declaration) indicates that: "In order to protect the environment, the precautionary approach shall be widely applied by States according to their capabilities. Where there are threats of serious or irreversible damage, lack of full scientific certainty shall not be used as a reason for postponing cost effective measures to prevent environmental degradation. ${ }^{71}$

The precautionary principle for food safety was codified at the Cartagena Protocol on Biosafety. The Protocol provides that: "Lack of scientific certainty due to insufficient relevant scientific information and knowledge regarding the extent of the potential adverse ... shall not prevent that Party from taking a decision, as appropriate, with regard to the import of that living modified organism ... in order to avoid or minimize such potential adverse effects. ${ }^{72}$ [Emphasis added] The precautionary principle has been applied in the EU, to the regulation of environmental protection, human health and safety as a basic legal principle. ${ }^{73}$ The precautionary principle was also reflected in Article 5.7 of the SPS Agreement, which allows provisional sanitary measures based on available pertinent information when the scientific evidence is insufficient for an assessment of risk. ${ }^{74}$ In EC-Hormones case, the Panel and the Appellate Body made it clear that the precautionary principle does not override Article 5.7.

Since human beings should not be an object of experiment for the sake of maximization of commercial benefits and expansion of free trade, the non-application of the precautionary principle counters human dignity. The value of human health and life cannot be sacrificed in the name of free trade. The protection of public health must take precedence over economic considerations. The passive and

70 On the precautionary principle in EC food law, international environmental law, international trade law, see $\mathrm{M}$. Echols, Food Safety and the WTO: The Interplay of Culture, Science and Technology 106-120 (2001); F. Perrez, Risk Regulation, Precaution and Trade, in Genetic Engineering and the World Trade System 246-284 (D. Wuger \& T. Cottier eds., 2008).

71 Rio Declaration princ. 15.

72 The Cartagena Protocol on Biosafety to the Covenant on Biological Diversity [hereinafter Cartagena Protocol on Biosafety] arts. 10.6 \& 11.8, available at http://bch.cbd.int/protocol/text (last visited on Feb. 25, 2013).

73 Supra note 69 , at 43.

74 SPS Agreement art. 5.7. It reads: "In cases where relevant scientific evidence is insufficient, a Member may provisionally adopt sanitary or phytosanitary measures on the basis of available pertinent information, including that from the relevant international organizations as well as from sanitary or phytosanitary measures applied by other Members. In such circumstances, Members shall seek to obtain the additional information necessary for a more objective assessment of risk and review the sanitary or phytosanitary measure accordingly within a reasonable period of time."

75 See EC-Measures concerning Meat and Meat Products (Hormons), WT/DS26/R/USA, Aug. 18, 1997, $\uparrow$ - 8.157-8.158; EC-Measures concerning Meat and Meat Products (Hormons), WT/DS48/AB/R/USA, Jan. 16, 1997, 125. 
negative application of the precautionary principle, based on the scientific evidence requirement, may result in enforcing undemocratic health policy, ignoring the concerns of the public about food safety. So long as human health or life is concerned, minority views on risk assessment should also be properly respected, in consideration of the precautionary principle and human dignity. ${ }^{76}$

\section{Measures to Protect Small and Medium Distribution Business Activities}

Measures regulating the business activities of major distribution enterprises may include licensing for businesses, restrictions on sale items, mandatory off-days, and mandatory closing times. Special protection for small and medium distribution business activities is necessary to promote and protect the economic and social rights of the weak who are engaging in small distribution business for survival. However, this kind of measure, restricting the business activities of bigger distribution enterprises, may be challenged by the WTO Members because such measures would be a violation of GATS, so long as a Member made full concessions in opening a market for distribution service on its Schedule. ${ }^{77}$ Article XVI of GATS prohibits, unless otherwise specified in its Schedule, the following six types of measures: (1) limitations on the number of service suppliers; (2) limitations on the total value of service transactions or assets; (3) limitations on the total number of service operations or on the total quantity of service output; (4) limitations on the total number of natural persons (5) measures which restrict or require specific types of legal entity or joint venture; and (6) limitations on the participation of foreign capital. ${ }^{78}$

With the increasing number of small businessmen injured by the expansion of free trade and investment, social integration has been impeded, which will prevent sound and sustainable regional economic integration. If small distribution companies and traditional markets collapse mainly due to trade liberalization such

76 In EC-Hormones, the Appellate Body held that: "The risk assessment could set out both the prevailing view representing the 'mainstream' of scientific opinion, as well as the opinions of scientists taking a divergent view. Article 5.1 does not require that the risk assessment must necessarily embody only the view of a majority of the relevant scientific community,..., especially where the risk involved is life-threatening in character and is perceived to constitute a clear and imminent threat to public health and safety." Id. ๆ 194.

77 E.g., an administrative order requesting mandatory suspension of business for two days per week, issued only to big distribution enterprises, may be inconsistent with article XVI.2 of GATS, because the order may result in "limitations on the total number of service operations or on the total quantity of service output." See GATS art. XVI.2(c).

78 GATS art. XVI.2. Under Article XVII.1 (National Treatment) of GATS, each Member must also accord to services and service suppliers of any other Member, in respect of all measures affecting the supply of services, treatment no less favorable than that it accords to its own like services and service suppliers, subject to any conditions and qualifications set out its schedule. 
as the expansion of FTAs, the business activities of major enterprises will flourish further. Hence, the rich get richer and the poor get poorer, which will cause serious social problems. In many countries like South Korea, this has resulted in the expansion of the anti-globalization movement.

Measures regulating business activities between small and big companies may be justified if it would promote 'public interests' such as the balanced development between small companies and big enterprises, sound development of rural and local community, promotion of economic democratization, ${ }^{79}$ maintenance of fair competition, consumer protection, etc. These measures may contribute to the harmonious development of the national economy and social integration. Free competition without any restrictions is unfair for small and medium companies; it cannot realize economic democratization.

To attain fair competition, the abuse of the dominant status of big enterprises should be prevented. Under GATS, e.g., each Member must ensure that any monopoly supplier of a service in its territory does not, in supplying a monopoly service in the relevant market, act in a manner inconsistent with that Member's obligations under Article II (Most-Favored-Nation Treatment) and specific commitments. ${ }^{80}$ Article VIII.2 of GATS also stipulates that where a Member's monopoly supplier competes, either directly or through an affiliated company, in supplying a service outside the scope of its monopoly rights and which is subject to that Member's specific commitments, the Member must ensure that such a supplier does not abuse its monopoly position to act in its territory in a manner inconsistent with such commitments.

79 'Economic democratization' here means to realize democratic system in the field of national economy through balanced economic development, proper allocation of incomes, prevention of the abuse of prominent status by big enterprises, harmonious development among subjects of national economy, and the public participation in decisionmaking of economic and trade policy. As pointed out by Petersmann, the democratic legitimacy of national and international constitutionalism is based on the protection and promotion of human rights in the economy no less than in the polity, and democratic participation of citizens in the exercise of national and international governmental powers. See E-U. Petersmann, Time for a United Nations 'Global Compact' for Integrating Human Rights into the Law of Worldwide Organizations: Lessons from European Integration, 13 EuR. J. INT'L L. 649-650 (2002). 


\section{Procedural Rules for Sustainable Economic Integration Ensuring Human Dignity}

Since economic integration has a great impact not only on the national economy, but also on people's daily life, individuals are entitled to participate directly or indirectly in the process of concluding and implementing trade agreements. Civic participation in trade rule-making and dispute settlement procedures would contribute toward ensuring the democratic legitimacy of trade rules and policies by enhancing transparency and credibility. Legitimacy also makes trade rule-enforcing and dispute settlement mechanisms more effective. Procedural rules to ensure the participation of individuals in the dispute settlement process will be proposed in this section.

\section{A. Right of Standing}

In order to protect fundamental human rights effectively, legal remedies must be provided to individuals who suffered due to the application and implication of regional economic integration agreements. However, under the WTO Agreement ${ }^{81}$ and the existing FTAs, only Members can bring trade disputes before the Dispute Settlement Body or arbitration panel. ${ }^{82}$ Individuals cannot bring a claim against Members having violated treaty obligations, because they do not have standing. Individuals get legal remedy, only if their government brings a claim against other Members by invoking the right of diplomatic protection under international law. ${ }^{83}$ It should be noted that under international law, individuals wronged by foreign State do not have a right to seek diplomatic protection from their government; ${ }^{84}$ the government will not provide diplomatic protection for its own citizens without considering its national interests and diplomatic relations with other States.

In the case of investment disputes, most of FTAs and Bilateral Investment Treaties ("BITs") provide that foreign investors are allowed to initiate investment arbitration against host States that have caused damage by violating treaty

81 Marakesh Agreement Establishing the World Trade Organization, Apr. 15, 1994, 33 I.L.M. 1144 (1994) [hereinafter WTO Agreement].

82 Like dispute settlement mechanisms in the WTO Agreement and FTAs, the International Court of Justice also allows only governments to have standing to initiate international claims. See ICJ Statute art. 34.

83 Supra note 27, at 121.

84 I. Brownlie, Principles of Public International Law 478 (7th ed. 2008). See also Barcelona Traction, Light and Power Company (Belg. v. Spain), Judgment, 1970 I.C.J. 3 9ף 44-45 (Feb. 5). 
obligations. The North American Free Trade Agreement ("NAFTA"), ${ }^{85}$ e.g., created a dispute settlement system for investment disputes allowing foreign investors to initiate arbitration proceedings against a NAFTA member. ${ }^{86}$ Such a direct legal remedy given to foreign investors may be extended to apply to other areas covered by economic integration agreements, including market access, movement of goods, and services in trade. ${ }^{87}$ If individuals are allowed to have standing under economic integration agreements, they can have recourse to a proper legal remedy through a claim to the appropriate arbitral panel or regional court. Complaining private parties can include individual victims, labor unions, and public interest groups. Their fundamental human rights can be thus invoked before such judicial systems, if infringed on by trade-related measures.

However, excessive standing for individuals may lead private parties to abuse direct remedy procedures, thus prohibiting more effective and amicable solutions between Members. It would impose too great a burden on the arbitral panel or regional court. For more effective protection of human dignity, proper limitations should thus be required for direct claims by private parties. E.g., individuals should be allowed to make a direct claim against a Member, only if they were directly affected by the measures or decisions taken by the Member or international enforcement organs in charge of administering regional economic integration. [Emphasis added]

\section{B. Amicus Curiae}

The submission of amicus curiae briefs by individuals may be also used as an effective means of protecting fundamental human rights, especially when private parties are not allowed to bring claims against a government that is violating treaty obligations. ${ }^{88}$ NGOs and individuals are allowed to submit unsolicited amicus curiae briefs to panels and the Appellate Body under the WTO Agreement. In US-Shrimp, the Appellate Body recognized NGOs' procedural right to submit amicus curiae

85 North American Free Trade Agreement, Dec.17, 1992, Canada-Mexico-USA, 32 I.L.M. 289 \& 32 I.L.M. 605.

86 NAFTA arts. $1116 \& 1117$. Regarding the special dispute settlement system for investment disputes of NAFTA, see D. Price, An Overview of the NAFTA Investment Chapter: Substantive Rules and Investor-State Dispute Settlement, 27 InT'L L. 717 (1993).

87 The European Court of Justice has jurisdiction over the actions brought by private parties challenging Community action or inaction or seeking damages from the Communities. See Consolidated Version of the Treaty Establishing the European Community arts. 230 (ex art. 173) \& 232 (ex art. 175).

88 The participation of private parties in the panel process is based on the right of the panel to seek information and technical advice from any individual or body that it deems appropriate. See DSU art. 13.1. 
briefs. ${ }^{89}$ The Appellate Body has also recognized the discretion of a panel either to accept or to reject the briefs submitted to it, whether requested by the panel or not. ${ }^{90}$

The submission of amicus curiae briefs by non-Members is also allowed under some FTAs. The Korea-Singapore FTA provides that the arbitral panel may consider requests from non-governmental entities to provide written views regarding the dispute that may assist the arbitral panel in evaluating the submissions and arguments of the Parties. ${ }^{91}$ The Korea-US FTA also lays down a similar provision. ${ }^{92}$ The Korea-US FTA further provides that the arbitration panel may receive unsolicited written submissions from interested natural or legal persons of the Parties, unless the Parties agree otherwise within three days of the date of the establishment of the arbitration panel. ${ }^{93}$ It should be noted that the Korea-EU FTA and Korea-Singapore FTA recognize the discretion of panels, while the Korea-US FTA imposes legal obligation on panels to consider amicus curiae briefs.

Amicus curiae briefs are also admitted in the NAFTA arbitral tribunals that do not have express provisions on non-disputing party participation. The NAFTA arbitral tribunal in the Methanex case decided that it had the power to accept amicus briefs and allowed petitioners to submit amicus briefs. ${ }^{94}$ In that case, the Tribunal noticed the petitioners' argument that there was an increased urgency warranting amicus participation in light of the award dated August 30, 2000, in Metaclad Corporation v. United Mexican States and in light of an alleged failure to consider environmental and sustainable development goals in that NAFTA arbitration. ${ }^{95}$

The primary purpose of amicus curiae briefs provided for in regional trade agreements is to allow third parties to invoke their rights before the arbitral panel or regional court with relevant information. Written submission of amicus curiae briefs by stakeholders may help arbitral panels understand specific facts, and may

See United States - Import Prohibition of Certain Shrimp and Shrimp Products, WT/DS 58/ AB/R, Oct. 12, 1998, 89.

See, e.g., United States - Import Prohibition of Certain Shrimp and Shrimp Products, WT/DS 58/ AB/R, Oct. 12, 1998

I 105; European Communities- Measures Affecting the Approval and Marketing of Biotech Products, WT/DS 291/R, WT/DS 292/R, WT/DS 293/R, 29, Sept. 2006, ๆๆ 7.10 \& 7.11; United States- Laws, Regulations and Methodology for Calculating Dumping Margins (“Zeroing”), WT/DS 294/R, Oct. 31, 2005, ๆ 1.7.

91 Free Trade Agreement between the Government of the Republic of Korea and the Government of the Republic of Singapore, art. 20.9 [hereinafter Korea-Singapore FTA], available at http://www.fta.go.kr/pds/fta_korea/singapore/ kor/KSFTA.pdf (last visited on Jan. 25, 2013).

92 KOR-US FTA art. 22.10, $₫ 1(\mathrm{e})$.

93 Id. art.11.1. However, the submission should be made within 10 days of the date of the establishment of the arbitration panel, be concise (in no case longer than 15 typed pages, including any annexes), and be directly relevant to the factual and legal issues under consideration by the arbitration panel. Annex 14-B (Rules of Procedure for Arbitration).

94 See Methanex Corpoaration v. United States of America, NAFTA, Decision of the Tribunal on Petitions from Third Persons to Intervene as 'Amici Curiae,' 2001, ๆ 6.

95 Id. 
facilitate fair and equitable solutions between the parties.

In this context, regional trade agreements should provide the following dispute settlement clauses in detail: (1) the scope of individuals who are allowed to submit amicus curiae briefs; (2) the nature of disputes that allows the submission of the briefs; (3) the contents of the briefs to be submitted; (4) the method of reviewing for consideration of the briefs; and (5) procedural guidelines for serving notice, time-limits, and formats. These clauses can enhance democratic and procedural legitimacy, the fairness of awards and judgments, and the public participation. For the protection of fundamental human rights, the submission of amicus curiae briefs must be recognized as a legal right of individuals to advocate their views and interests in front of arbitral panels or tribunals, and be imposed on Members as a legal obligation requiring them to consider properly these views during the dispute settlement process. ${ }^{96}$

\section{Right to Petition}

Along with the submission of amicus curiae briefs, the right to petition may be used by individuals as an effective means of protecting fundamental human rights, especially when they do not have standing to bring a claim against a government in violation of treaty obligations. With the right to petition, individuals are entitled to petition the regional economic integration commission or free trade commission, if measures taken by governments to implement regional economic agreement impair their fundamental human rights.

There are few FTAs that recognize the right to petition for individuals. The Korea-US FTA, however, gives the Labor Affairs Council the privilege to receive and review complaints brought by individuals, then to advise labor and business organizations on the implementation of labor provisions under the FTA. ${ }^{97}$ Each party must review such complaints, as appropriate, in accordance with domestic procedures. ${ }^{98}$

The right of individuals to petition has been developed as an effective system for international protection of human rights. For example, the Optional Protocol to the International Covenant on Civil and Political Rights ${ }^{99}$ recognizes the right of individuals, subject to the jurisdiction of a party to the Protocol, to petition. The

96 C. Joerges \& E.-U. Petersmann, Constitutionalism, Multilevel Trade Governance and International Economic LAW 471 (2011).

97 KOR-US FTA art. 19.5.

98 Id. art. 19.5.3.

99 G.A. Res. 2200A (XXI), 21 U.N. GAOR Supp. (No. 16) at 59, U.N. Doc. A/6316 (Dec. 16, 1966), 999 U.N.T.S. 302. 
Protocol recognizes the right of individuals to submit written communications to the UN Human Rights Committee for consideration; ${ }^{100}$ the Committee must then bring any communications submitted to it under the Protocol to the attention of the State Party to the Protocol having violated any provision of the Covenant. ${ }^{101}$ The Committee must forward its views to the State Party concerned and the individual, as well. ${ }^{102}$ This monitoring mechanism proved "a balanced and relatively effective means of impelling States to live up to their international undertakings." ${ }^{103}$

The petition system for individuals may prevent trade disputes involving the public's interests from being escalated into disputes between States. Accordingly, an individual or a group of individuals must be allowed to petition the regional economic integration commission or the free trade commission to consider any matters or disputes arising out of any interpretation, application, or implementation of regional economic integration agreement.

\section{Other Procedural Rules for Public Participation and Transparency}

The full disclosure of information and government measures affecting individuals may be also used as an effective means of protecting fundamental human rights by enhancing public participation in trade policy-making and implementing economic integration agreement at the national and international level. Without sufficient information, individuals cannot effectively make a claim or complaint against the violation of human rights by governments or companies. Regional economic integration agreement must, therefore, provide individuals with procedural rules that ensure the participation of stakeholders in the process of trade negotiation, implementation of trade agreements, and dispute settlement procedures.

In United States - Restrictions on Imports of Cotton and Man-made Fiber Underwear case, the Appellate Body recognized the importance of transparency and information disclosure to individuals as follows:

Article X:2, General Agreement, may be seen to embody a principle of fundamental importance - that of promoting full disclosure of governmental acts affecting Members and private persons and enterprises, whether of domestic or foreign

\footnotetext{
100 First Optional Protocol to the International Covenant on Civil and Political Rights art. 2, 999 U.N.T.S. 171, Dec. 16, 1966, available at www.ohchr.org/engish/law/ccpr-one.htm (last visited on Apr. 8, 2013).

101 Id. art. 4.1. Within six months, the receiving State must submit to the Committee written explanations or statements clarifying the matter and the remedy, if any, that may have been taken by that State. Id. art. 4.2.

102 Id. art. 5.4.

103 Supra note 27, at 293.
} 
nationality. The relevant policy principle is widely known as the principle of transparency and has obviously due process dimensions. The essential implication is that Members and other persons affected, or likely to be affected, by governmental measures imposing restraints, requirements and other burdens, should have a reasonable opportunity to acquire authentic information about such measures and accordingly to protect and adjust their activities or alternatively to seek modification of such measures. ${ }^{104}$

In order to facilitate individual participation in dispute settlement procedures, some FTAs request each party's written submission to be made available to the public. Without the disclosure of submission, it may be very hard both to submit amicus curiae briefs containing timely and sufficient information, and to encourage the public participation in the process of dispute settlement. For example, the KoreaSingapore FTA, the US-Singapore FTA, ${ }^{105}$ the Korea-US FTA and the China-New Zealand FTA $^{106}$ all provide that a party's written submission, written versions of its oral statements, and written responses to a request or questions, except confidential information from the panel, must be made available to the public. The ChinaSingapore FTA also stipulates that a party must provide a non-confidential summary of the information contained in its submissions that can be disclosed to the public, when it submits a confidential version of its written submissions to the arbitral tribunal. ${ }^{107}$ The US-Singapore FTA provides that if the consultations fail to resolve the dispute within 60 days of the delivery of a party's request for consultations, either party may, by delivering written notification to the other party, refer the matter to the Joint Committee, which must endeavor to resolve the dispute, and that each party must solicit and consider the views of members of the public in order to draw upon a broad range of perspectives, after requesting or receiving a request for consultations by the other party. ${ }^{108}$

104 WT/DS24/AB/R, Feb. 10, 1997, at 21.

105 The United States - Singapore Free Trade Agreement [hereinafter US-Singapore FTA], available at http://www.ustr. gov/trade-agreements/free-trade-agreements/singapore-fta/final-text (last visited on Mar. 15, 2013).

106 Free Trade Agreement between the Government of New Zealand and the Government of the People's Republic of China [hereinafter China-New Zealand FTA], available at http://rtais.wto.org/UI/PublicShowRTAIDCard. aspx?rtaid=664 (last visited on Mar. 15, 2013).

107 The China - Singapore Free Trade Agreement art. 99.4 [hereinafter China-Singapore FTA], available at http://rtais. wto.org/UI/PublicShowRTAIDCard.aspx?rtaid=496 (last visited on Mar. 15, 2013).

108 US-Singapore FTA art. 20.4.2. 


\section{Conclusion}

Maximizing trade benefits through market-opening measures is not the ultimate goal, but a tool of regional economic integration. The main purpose of trade liberalization is to promote and enhance human dignity. Fundamental human rights, including jus cogens under international law, ${ }^{109}$ cannot be sacrificed for the sake of economic benefit. Since the principle of human dignity is a basic norm justifying all legal regulations and institutions, it must have priority over trade and investment liberalization. Human dignity may, therefore, function as an indispensable requirement for sustainable regional economic integration, considering the different political systems, religions, and cultures of the world, especially those in East Asia. Economic integration ensuring human dignity will promote successful and sustainable regional economic integration, by balancing economic prosperity and social integration.

Since economic integration has a great impact not only on the national economy but also on peoples' daily lives, individuals should be entitled to participate directly or indirectly in the process of concluding and implementing trade agreements. If individuals are allowed to have standing under economic integration agreements, they can access proper legal remedies by bringing a claim to the arbitration panel or regional court. The submission of amicus curiae briefs by individuals and the right to petition may be also used as an effective means of ensuring human dignity, especially when they are not allowed to claim damages against a government that has violated treaty obligations.

Trade rules should be consistent with human rights norms because fundamental human rights have been established as customary international law. Proper provisions for tariff reductions, SSG measures, domestic support, and export restrictions should be thus included in economic integration agreements in order to ensure fundamental social and economic rights, including the rights to food and an adequate standard of living, the rights to health and life, and labor rights.

109 Although the scope of jus cogens under international law is controversial, there is considerable agreement that jus cogens include the prohibition of the use of force, genocide, slavery, gross violation of the right of people to selfdetermination, racial discrimination, and torture. Throughout this article, the author contends that jus cogens should also include some basic or fundamental human rights, such as the rights to food and adequate standard of living. For details on the scope of jus cogens in human rights, see P. Malanczuk, Akehurst's Modern Introduction to International Law 57-58 (7th ed. 1997); J. Frowein, Jus Cogens, 7 Encyclopedia of Public International Law 328329 (R. Bernhardt ed., 1984); P. Weil, Towards Relative Normativity in International law?, 77 Am. J. INT'L L. 413442 (1983); L. Hannikainen, Peremptory Norms in International Law: Historical Development, Criteria, Present STATUs (1988). 
Since economic democratization may facilitate the social integration necessary for sustainable regional economic integration by contributing to the protection of human dignity, measures to protect small and medium distribution business activities may also be used as an effective means of protecting fundamental human rights. It should be noted that "in a world of growing interdependence and complexity and the internationalization of production, the fundamental values of freedom, human dignity, social justice, security, and non-discrimination are essential for sustainable economic and social development and efficiency." ${ }^{\text {110 }}$ 
